\title{
IDENTIFIKASI JELAJAH GEOLOGI GUNUNG API PURBA GUNUNG IRENG DESA PENGKOK, KABUPATEN GUNUNGKIDUL
}

\author{
Sri Mulyaningsih ${ }^{1}$, Nur Widi Astanto Agus Tri Heriyadi ${ }^{2}$, Dina Tania ${ }^{3}$ dan, Suhartono ${ }^{4}$ \\ ${ }^{1}$ Teknik Geologi-FTM IST AKPRIND, sri_m@akprind.ac.id \\ ${ }^{2}$ Teknik Geologi-FTM IST AKPRIND, nurwidi@akprind.ac.id \\ ${ }^{3}$ Teknik Geologi-FTM IST AKPRIND, dina_tania@akprind.ac.id \\ ${ }^{4}$ Teknik Industri-FT-UWMY, sharjosaputro7@gmail.com
}

\begin{abstract}
ABSTRAK
Gunung Ireng di Desa Pengkok adalah destinasi wisata baru geologi gunung api purba di Kecamatan Patuk, Kabupaten Gunungkidul, di samping Gunung Nglanggeran. Selain aglomerat, sebagaimana penciri geologi Gunung Api Purba Nglanggeran, breksi vulkanik, lava bersruktur meniang, dike, dan blocky lava berkomposisi andesit menyusun Gunung Ireng. Makalah ini disusun untuk mengidentifikasi kealamian jelajah alam geologi gunung api purba Gunung Ireng sebagai destinasi wisata minat khusus geowisata. Metode yang digunakan adalah studi dan analisis konektivitas Gunung Ireng terhadap destinasi-destinasi wisata lain di sekitarnya dan identifikasi keragaman data geologinya. Penelitian menjumpai morfologi bukit melingkar berbentuk kubah, yang dikelilingi lembah berslope $\sim 30-55^{\circ}$ yang melandai ke baratlaut. Dari atas bukit terlihat Gunung Wayang (Nglanggeran di ujung timur), karst Selopamioro di arah selatan, Sudimoro di arah barat dan tinggian Patuk di sebelah utara. Jalur konektivitas telah menghubungkan Gunung Ireng dengan Gunung api Nglanggeran-Oro-Oro, Dlingo, Selopamioro dan Kali Ngalang-Gedangsari. Promosi dan dukungan sepenuhnya dari pemerintah Kabupaten Gunungkidul, serta optimisme pengelola adalah kunci keberhasilan Gunung Ireng untuk disejajarkan dengan destinasi-destinasi wisata minat khusus lain di sekitarnya; mendukung keberlanjutan Geopark Gunung Sewu.
\end{abstract}

Kata kunci: identifikasi, jelajah, wisata, geologi, gunung api, purba, dan Gunung Ireng

\section{Identifying Ancient Volcano Adventure Trip Of Gunung Ireng-Pengkok Village, Gunungkidul Regency}

\begin{abstract}
Mount Ireng at Pengkok is a new ancient volcanic tourist destination besides Mount Nglanggeran (Gunungkidul Regency). Agglomerate, which is the primadonna of Mount Nglanggeran, together with other varying volcanic rocks are worthy of being called an ancient volcano. The volcanic neck constituents (lava domes, dike, breccia and blocky lava), autoclastic breccia and tuff (of Semilir Formation) are composing Mount Ireng, so that hypothesized as ancient volcano. This paper was prepared to identify the natural potential of Mount Ireng to be developed as a special interest tourist destination exploring ancient volcano. The method used is study and analyse the connectivity of Mount Ireng to other tourist destinations in its vicinity and identify the natural geology of the ancient volcano. The results of study found a dome-shaped circular hill surrounded by valleys with a slope of $\sim 30-55^{\circ}$ sloping to the northwest. Its composed of andesitic dike, lava, breccia, blocky lava and agglomerates. From the top of the hill is Mount Wayang (Nglanggeran) on the east end, Selopamioro karst in the south, Sudimoro hills on the west and Patuk high on the north. The connectivity path that connects Nglanggeran Palaeo-volcano and Oro-Oro, Dlingo Tourism areas, Selopamioro Tourism Village and Ngalang River (Gedangsari), is a separate force for Mount Ireng. Through the promotion and full support of the Gunungkidul government, as well as high optimism of the manager will be the key to the success of Mount Ireng to be aligned with other
\end{abstract}

ISSN: 2355-6587, e-ISSN: 2528-2220

http://ejournal.bsi.ac.id/ejurnal/index.php/jp 
special interest tourist destinations in the vicinity, while supporting the sustainability of Geopark Gunung Sewu.

Keywords: identification, adventure, tourism, geology, volcano, ancient and Mount Ireng

\section{PENDAHULUAN}

Wisata geologi ("geowisata") saat ini telah menjadi primadona di industri pariwisata di Indonesia, menyusul kisah sukses destinasi Gunung Api Purba Nglanggeran di Kecamatan Patuk, Kabupaten Gunungkidul (Hermawan, 2017; Purbasari \& Asnawi, 2014). Wisata jelajah alam yang menggali berbagai potensi dari sisi geologi, biologi (flora dan fauna), topografi, dan bekas area tambang; seperti Bukit Cinta Watuprau (Bayat), Lava Bantal Jogotirto, Tebing Breksi, Watulimo, Karst dan lain-lain semakin digemari pengunjung (Dominikus, 2018; Rahmawati, 2017; dan Syakdiah, 2018). Hal itu, karena geowisata dipandang lebih identik dengan langkah konservasi lingkungan dan lahan, yang berwawasan lingkungan (Hermawan, 2018; Hermawan \& Ghani, 2018), ketimbang ekstraksi sumber daya alam, sehingga diklaim dapat bersifat sustainable (Annisa, 2016; Hermawan \& Brahmanto, 2017).

Geowisata yang dikelola dengan berbasis masyarakat tentu akan menambah ketahanan masyarakat desa, seperti yang telah dilakukan di Gunung Nglanggeran (Rosida, 2014), Desa Mangunan (AlBakry, 2013), dan Desa Wisata BobungDlingo (Pratama \& Kistini, 2013). Sayangnya, tak-jarang geowisata dipaksakan dibangun sebagai implikasi dari keberadaan geopark yang lebih bersifat regional di daerahnya; misalnya Ciletuh (Andriany dkk., 2016; Darsiharjo, 2016; Hadian dkk., 2016; Yuliawati dkk., 2016; Zakaria, 2018), Karst Gunung Sewu (Kusumayudha dkk., 2015; Permadi dkk.,
2014; Tyas dkk., 2016), Bakkara-Toba (Ginting dkk., 2017) dan lain-lain. Pengelolaan yang kurang pas, dapat saja mempengaruhi stabilitas lingkungannya, yaitu berpotensi membentuk bencana baru, seperti abrasi oleh perubahan bentuk lahan, depresi dan gerakan massa akibat beban antropogen berlebih pada lahan yang miring, dan lain-lain (Evita dkk., 2012; Umardiono, 2011). Dampak lainnya adalah perubahan sosial, ekonomi, budaya dan perilaku masyarakat setempat (Sidarta, 2002; Nurjanah, 2012). Logikanya, masyarakat lokal (sebagai pemilik lahan) akan lebih berhati-hati dalam mengelola hak miliknya; memperhatikan potensi negatifnya dibandingkan pananam modal asing yang rasa memilikinya kurang dibandingkan pemiliknya sendiri (Arbainah, 2014; Raharjana, 2012; Martiarini, 2017).

Desa Pengkok di Kecamatan Patuk, Kabupaten Gunungkidul (Gambar 1) memiliki potensi geowisata tersebut; didukung oleh warisan geologi gunung api purba Gunung Ireng (Mulyaningsih dkk., 2019; Blessia dkk., 2019; Simbolon dkk., 2019). Penanganan secara bijaksana terhadap kondisi geologi Gunung Ireng, yang salah satunya melalui pengembangan geowisata akan dapat menjembatani potensi perilaku berwisata amoral menjadi bermartabat, sekaligus berkonservasi dari kerusakan yang mungkin akan ditimbulkan oleh perilaku wisata tersebut. Geotourism Gunung Api Purba Ireng didekati melalui geoedukasi dan minat khusus geologi gunung api purba.

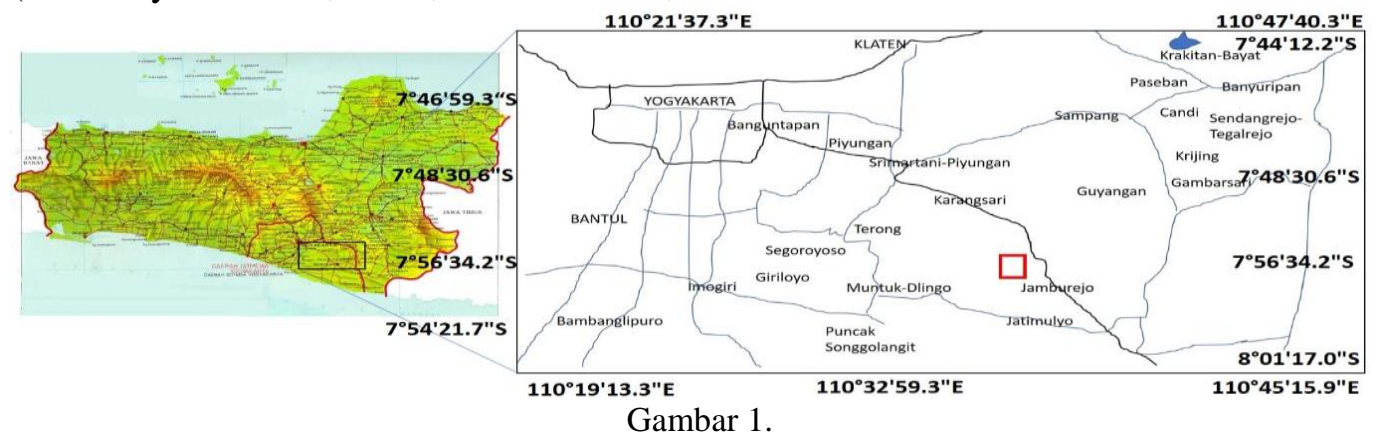

Peta kesampaian lokasi dan situasi Gunung Ireng

ISSN: 2355-6587, e-ISSN: 2528-2220

http://ejournal.bsi.ac.id/ejurnal/index.php/jp 
Secara geologi, pada Miosen TengahAkhir (belasan juta tahun yang lalu) Pegunungan Baturagung adalah gunung api purba bawah laut; sebagai bagian dari busur vulkanik Jawa berumur Tersier, akibat penunjaman lempeng IndiaAustralia di bawah lempeng Eurasia (Hamilton, 1979 dalam Mulyaningsih dkk., 2019). Aktivitas gunung api itu telah membentuk batuan yang menyusun Formasi Kebo-Butak, Formasi Semilir dan Formasi Nglanggeran, yang berselingan dan ditumpangi oleh batuan sedimen bawah laut (Gambar 2). Aktivitas vulkanisme berulang diikuti dengan pengangkatan Pegunungan selatan yang juga secara berulang, menjadikan kondisi geologi Pegunungan Selatan kurang stabil, meskipun batuan yang menyusunnya memiliki resistensi yang tinggi. Gunung Ireng dan Gunung Nglanggeran adalah bagian dari Pegunungan Baturagung tersebut, sehingga batuannya didominasi oleh batuan asal vulkanik Formasi Nglanggeran.

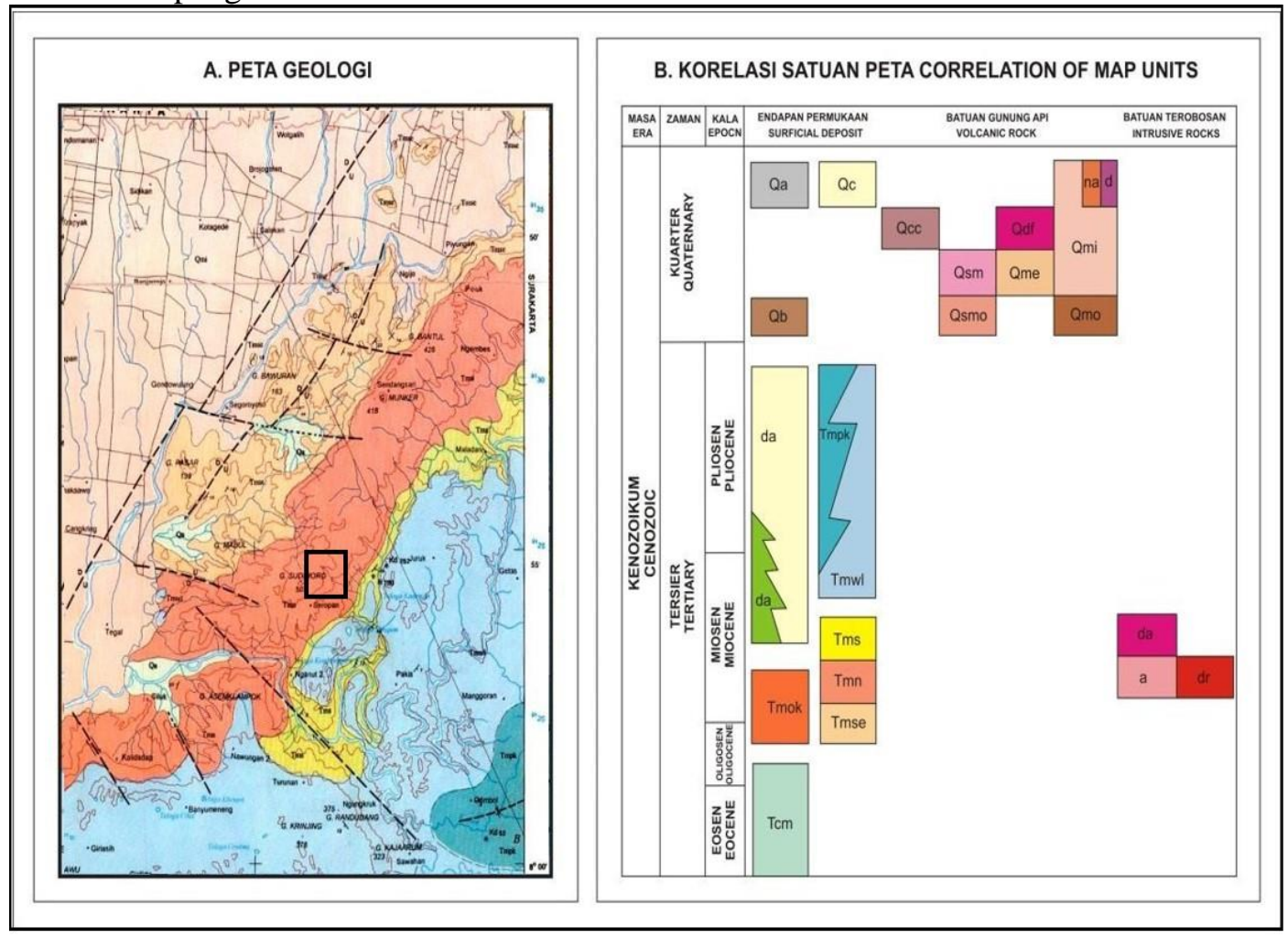

Gambar 2.

Sebagian Peta Geologi Lembar Yogyakarta (A) dan Stratigrafi umum Pegunungan Selatan Yogyakarta (B) (Rahardjo, dkk, 1995)

Formasi Nglanggeran ditunjukkan dengan warna coklat kemerahan, sedangkan warna coklat muda (krem) adalah Formasi Semilir yang tersusun atas breksi pumis dan tuf yang dihasilkan oleh erupsi tipe eksplosif yang mampu meruntuhkan sebagian besar tubuhnya.

\section{KAJIAN LITERATUR}

Interkoneksi destinasi wisata tergantung pada strategi pengelola dalam berkompetisi menarik pengunjung. Pada dasarnya tiaptiap pengelola akan menggunakan strategi bisnis sesuai dengan atraksi wisata yang ditawarkan; secara efisien dengan banyak variabel yang bisa dituju melalui sistem internkoneksinya. Kini, terjadi pergeseran perilaku wisatawan dari leisure tours pada era sebelumnya ke experience tours yang disebut esteem tours (Wang \& $\mathrm{Xu}, 2015$ ). Awalnya tujuan berwisata hanya menikmati waktu senggang dengan kumpul-kumpul bersama teman atau keluarga melalui wisata sun, sand, dan sea; kini telah berubah menjadi mencari pengalaman (experiences) dengan unsur 
ingin mendapatkan pengakuan karena pernah mengunjungi tempat-tempat yang lagi hits pada masanya. Perubahan perilaku berwisata tersebut lebih dipicu oleh addicted terhadap gadget terutama smartphone. Keunikan esteem tours adalah orang-orang tidak lagi mencemaskan pengorbanan dalam perjalanannya; rela bermacet ria atau bahkan merelakan nyawanya demi mendapatkan photo views yang up to date. Inilah tantangan utama dalam studi interkoneksi ini.

Variabel utama interkoneksi adalah (1) jaringan internet yang cepat dalam kapasitas bandwidth yang besar; untuk dapat dengan segera meng-update foto yang telah diperolehnya, (2) view alam yang mendukung untuk update foto diri; termasuk di dalamnya adalah keunikan data geologi (kealamian) gunung api purba, (3) kealamian yang bersifat menantang; sehingga jiwa jelajah yang dimiliki tersebut dapat diexplore sedalamdalamnya, untuk selanjutnya diunggah pada sosial media, (4) prasarana transportasi (kendaraan, jalan dan tempat parkir), dan (5) sarana pendukung (homestay, tempat ibadah, pasar dan lainlain) (Surgawi \& Sutopo, 2016).

Uji korelasi destinasi wisata sangat diperlukan dalam pengembangan destinasi wisata (Mulyaningsih dkk., 2019b). Variabel wisata yang digunakan dalam uji korelasi tersebut adalah (1) accesibility; yaitu kemudahan untuk dikunjungi dan memiliki jalan yang dapat dilalui kendaraan, (2) accommodation; yaitu kemudahan mendapatkan tempat menginap yang layak, bersih dan ramah, aman, dan memenuhi persyaratan sanitasi yang sehat (hotel, resort, hostel, losmen, guest house), (3) attraction; yaitu atraksi yang dikelola oleh pemerintah atau masyarakat setempat yang layak serta aman untuk dilakukan oleh para wisatawan, (4) activities; tersedianya sarana untuk melakukan kegiatan yang menyenangkan dan aman di daerah tujuan wisata, dan (5) amenities; yaitu fasilitas yang menunjang perjalanan wisata, berupa telepon, tempat penukaran uang, ATM, toko, restoran, toilet yang memadai, kantor pos, cinderamata, pasar, internet, media sosial, dan lain-lain. Untuk mendukung industri pariwisata hingga dapat mengangkat perekonomian, perlu memahami karakteristik destinasi wisata. Artinya, pengelola harus mampu menjamin ketersediaan akomodasi, jasa boga dan restoran, transportasi dan jasa angkutan, tempat penukaran uang, cinderamata dan biro perjalanan untuk para pengunjung.

Banyak sekali tipe gunung api di dunia; dengan tatanan geologinya, sifat dan tipe erupsinya, dan tipe dan susunan material hasil aktivitasnya dan keterdapatannya (Mulyaningsih, 2015). Hal itu dipengaruhi oleh tatanan tektoniknya; sebagai busur vulkanik dengan tipe magma Ca-alkalin (lebih encer) hingga $\mathrm{K}$-alkalin (sangat kental), gunung api Hotspot dan busur pemekaran dengan tipe magma tholeiit yang sangat encer seperti air, dan gunung api belakang busur dengan tipe magma shoshonit yang kaya akan unsur $\mathrm{K}$ (Mulyaningsih, 2015). Karena terbentuk dan dipengaruhi oleh aktivitas tektonik, maka tubuhnya selalu terdeformasi dengan pola tertentu (Mulyaningsih, 2019a).

Pada pertumbuhan gunung api busur vulkanik, seperti yang dijumpai di Pegunungan Baturagung, litologi yang menyusunnya sangat spesifik, tersusun atas perlapisan breksi dan lava yang sesekali diterobos oleh dike (retas) andesit/basalt. Susunan litologi tersebut disebut strato; tubuh gunung api yang dibentuknya adalah kerucut, seperti Gunung api Merapi. Secara umum, tubuh gunung api strato dapat terbagi atas tiga fasies berdasarkan susunan batuannya dan kelerengannya; yaitu fasies pusat, fasies proksimal, fasies medial dan fasies distal (Mulyaningsih, 2015). Namun, gunung api yang telah mati dan tererosi, apalagi telah terdeformasi secara berulang, sangat sulit untuk diidentifikasi fasies-fasiesnya. Mengacu pada Bogie \& McKenzie (1997 dalam Mulyaningsih, 2015) fasies pusat gunung api dicirikan oleh keberadaan aglomerat di permukaan yang menumpang di atas batuan alterasi, intrusi dike dan beberapa lava; sedangkan fasies pusat gunung api lebih didominasi oleh perlapisan breksi piroklastika dan lava. Identifikasi gunung api purba Gunung Ireng mengacu pada prinsip dasar fasies gunung api menurut

ISSN: 2355-6587, e-ISSN: 2528-2220

http://ejournal.bsi.ac.id/ejurnal/index.php/jp 
Bogie \& McKenzie (1997 dalam Mulyaningsih, 2015).

Secara detail, batuan gunung api yang tersusun atas lava berstruktur meniang dan lapisan tipis tuf-lapilli tak-terelaskan sering menyisip sebagai batas sekuen (Andrews et al., 2008; Gambar 2.a). Stratigrafi batuan gunung api pada jalur magmatik di Amerika Tengah, yang salah satunya berada pada Gunung Api El Chiocon, fasies pusatnya tersusun atas perselingan batuan kubah lava dengan pumis dan breksi piroklastika yang secara umum berkomposisi andesitan (Arche et al., 2014 dalam Mulyaningsih dkk., 2019a; Gambar 2.b). Susunan stratigrafi batuan gunung api itu juga sama dengan susunan stratigrafi batuan gunung api pada fasies pusat Gunung api Merapi (Andreastuti, 1999 dalam Mulyaningsih dkk., 2019a). Sementara itu, stratigrafi batuan gunung api yang dijumpai pada fasies sentral hingga distal dapat dilihat pada Gambar 3 mengacu Williams \& McBirney (1979) dan Vessel \& Davies (1981 dalam Smith, 1991 dalam Mulyaningsih dkk., 2019a).

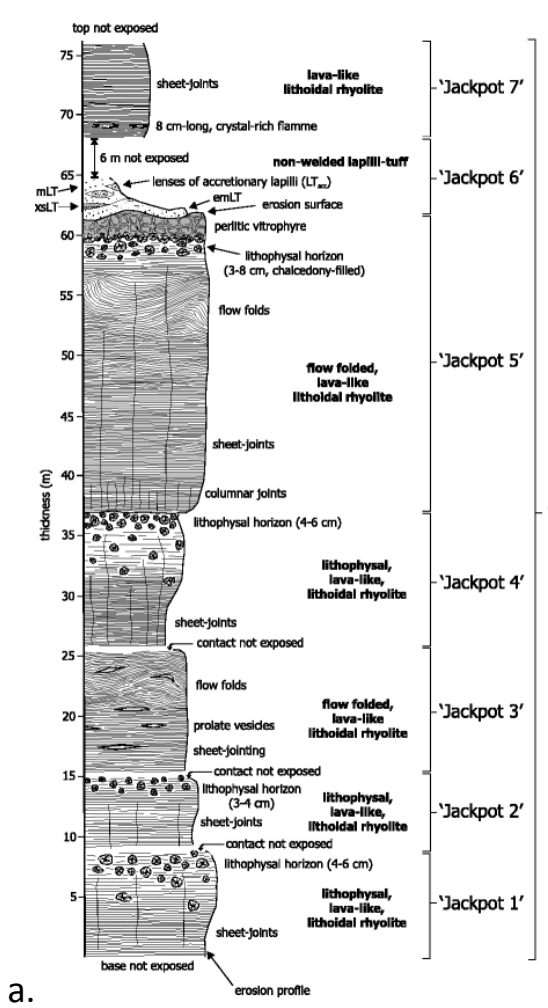

a.
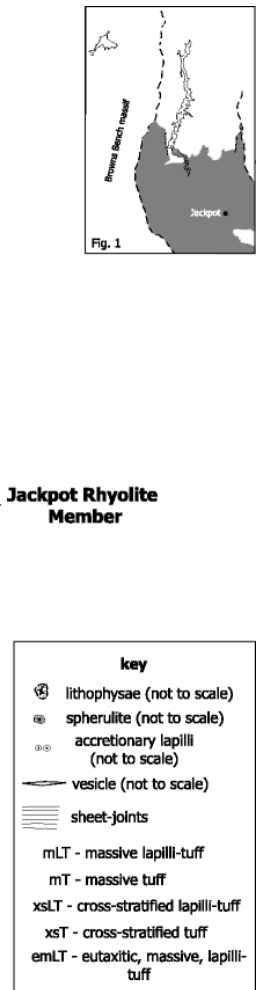

Gambar 3.

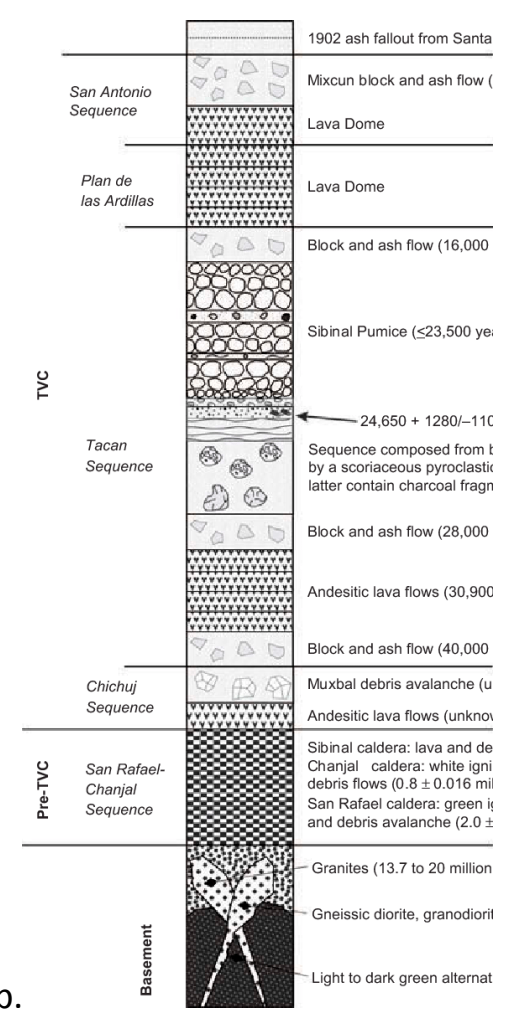

b.

a. Stratigrafi batuan gunung api riolitik di Rogerdson (Andrews et.al, 2008), dan b. Stratigrafi batuan gunung api pada Chiapanecan (El Chicon Volcano) dan busur vulkanik Amerika Tengah (Arce et al., 2014 dalam Mulyaningsih dkk., 2019a).

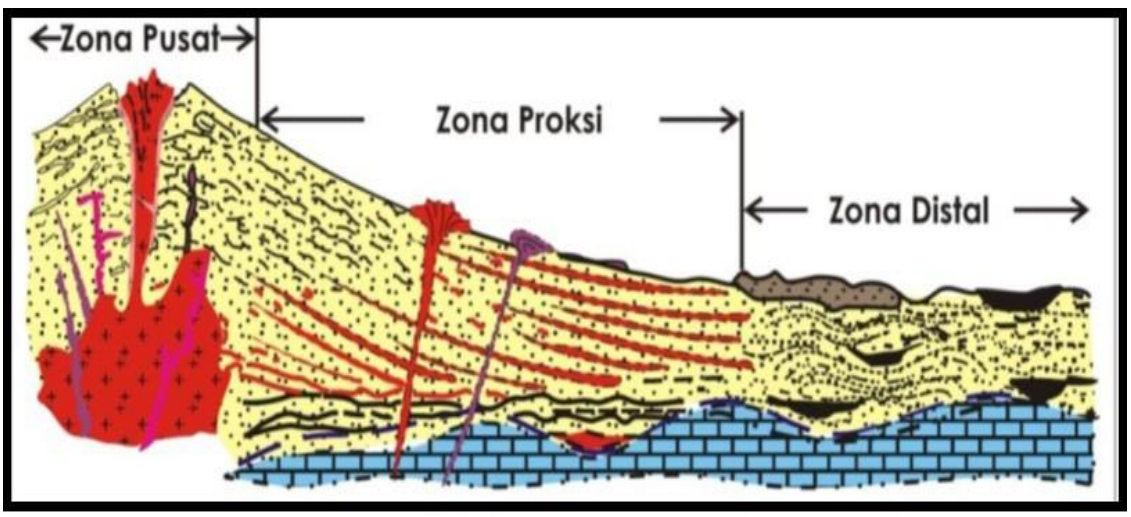

ISSN: 2355-6587, e-ISSN: 2528-2220

http://ejournal.bsi.ac.id/ejurnal/index.php/jp 


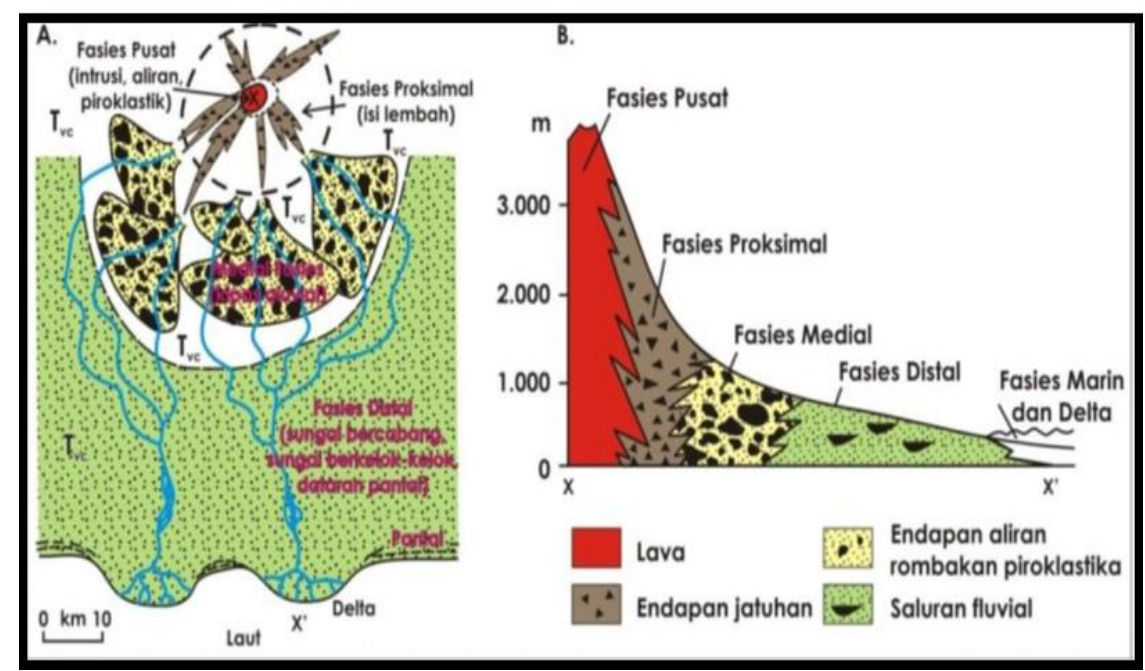

Gambar 4.

Fasies gunung api: pusat, proksimal, medial dan distal, (Williams \& McBirney, 1979 (atas) dan Vessel \& Davies, 1981 dalam Smith (1991; bawah) dalam Mulyaningsih dkk., 2019a).

\section{METODE PENELITIAN}

Metode penelitian yang digunakan adalah analisis konektivitas jelajah alam berpusat di Gunung Nglanggeran, identifikasi keanekaragaman geologi gunung api Gunung Ireng, dan identifikasi pemberdayaan potensi sumber daya masyarakat lokal. Data geologi gunung api dilakukan melalui pengumpulan dan pengukuran data stratigrafi batuan gunung api. Stratigrafi adalah studi mengenai sejarah, komposisi, umur dan distribusi suatu batuan guna merekonstruksi seluruh kejadian dan uruturutan proses pembentukannya (Mulyaningsih, 2016). Pengumpulan data geologi gunung api diawali dengan pengumpulan dan pengukuran data stratigrafi. Stratigrafi dipelajari untuk mengetahui luas penyebaran lapisan batuan dan hubungan antar masing-masing batuan.

\section{PEMBAHASAN}

Hasil analisis interkoneksi dan analisis korelasi terhadap variabel-variabel pariwisata di Tebing Breksi, Gunung Nglanggeran, area Dlingo (Nganjir, Puncak Becici dan Kakilangit Mangunan) memiliki ke-lima variabel dengan baik, sementara itu gunung Ireng dengan spesifikasi geologi gunung api, sun set dan sun rise, yang belum memiliki nilai pengembangan industri yang lebih baik terlihat begitu tertinggal jauh (Tabel 1). Bisa jadi, karena faktor promosi dan kebaruannya yang belum terpublikasi dengan baik. Tebing Breksi dan Kakilangit (Mangunan) meskipun lebih baru, namun memiliki intensitas promosi yang tinggi, sehingga masih sangat diinginkan oleh pengunjung.

Dalam lingkup $1 \times 1 \mathrm{~km}$ ke arah selatan, barat, utara dan timur, menurut Budayana (2017), litologi yang dapat dijumpai di daerah penelitian adalah breksi andesit Formasi Nglanggeran berumur Miosen Tengah; napal dan batupasir karbonatan Formasi Oyo dan batugamping berlapis Formasi Wonosari (berumur Miosen Tengah-Atas-Pliosen).

Pengukuran stratigrafi telah dilakukan pada tujuh jalur lintasan di daerah penelitian (Gambar 4). Data yang berhasil ditemukan adalah lava andesit berstruktur kekar kolom yang diintrusi oleh dike andesit dan ditumpangi oleh aglomerat dan breksi andesit.

Didasarkan pada kondisi kealamian, sarana dan prasarana geowisata, keinginan dan keberpihakan masyarakat terhadap pengembangan destinasi Gunung Ireng, maka dapat dideskripsi strength (kekuatan), weaknes (kelemahan), oportunities (peluang) dan threat (ancaman) pada Tabel 2. Hasil analisis SWOT ini mengindikasikan Gunung Ireng memiliki potensi untuk dapat dikembangkan sebagai destinasi wisata alam (atraksi dan aktivitinya), namun

ISSN: 2355-6587, e-ISSN: 2528-2220

http://ejournal.bsi.ac.id/ejurnal/index.php/jp 
membutuhkan pengembangan pendukung meliputi akses jalan, ameniti (sarana pendukung seperti toilet, ATM, internet dan lain-lain. Gunung Ireng juga membutuhkan sistem pengelolaan yang lebih baik, sehingga lebih dapat dikenal di dunia yang lebih luas.

Data DEM (Digital Elevation Model) menjumpai dua tinggian, yaitu Gunung Ireng dengan bentang alam melingkar dan Gunung Nglanggeran dengan bentang alam elipsoidal. Vulkano-stratigrafi gunung api purba Gunung Ireng dapat dikatakan sangat spesifik, warnanya yang ireng (hitam) sangat berbeda dibandingkan gunung api-gunung api purba yang lain di sekitarnya.

Secara detail lava andesit porfiri tersingkap luas di sisi selatan, barat, utara dan timur. Lava di sisi selatan-barat dicirikan oleh warna abu-abu terang agak kecoklatankehitaman, blocky, hipokristalin, subhedral-anhedral, porfiritik, tersusun atas andesine $\sim 30 \%$ dan aegirin $\sim 20 \%$ yang tertanam dalam masa dasar gelas dan kristal tak-teridentifikasi, tebal lava $\sim 10 \mathrm{~m}$ (Gambar 5.c). Di atas blocky lava adalah lava andesit berstruktur meniang, abu-abu gelap, tebal sekitar $\sim 10 \mathrm{~m}$ secara berulang.
Secara mikroskopis, lava dicirikan oleh vesikuler, porfiritik-poikilitik, subhedral, tersusun atas andesin $\sim 35 \%$ dan aegirinaugit $\sim 20 \%$, mineral opaque $\sim 5 \%$ dan massa dasar gelas dan kristal (Gambar 6.c). Beberapa bagian lava berbentuk blocky setebal 3-5m, dan secara gradual ditumpangi aglomerat. Ke arah barat, kurang lebih $200 \mathrm{~m}$ dari lava tersebut berupa lava massive (structureless) setebal lebih dari $5 \mathrm{~m}$ dan aglomerat yang di dalamnya banyak dijumpai mineralmineral sulfida, yaitu pirit (Gambar 5.d). Lava dicirikan oleh warna abu-abu gelap hingga kehitaman agak kehijauan, masif, porfiritik, tersusun atas labradorit-andesin $\sim 40 \%$, augit $\sim 20 \%$ dan mineral sulfida berbentuk isometris $\sim 5 \%$ berdiameter $0,2 \mathrm{~mm}$ (pirit) dan massa dasar kristal dan gelas. Di sisi lain, lava ini juga ditumpangi oleh breksi andesit abu-abu berfragmen andesit-basaltis, masif sortasi jelek, kemas terbuka, bentuk butir sangat menyudut, di dalamnya banyak dijumpai pirit. Tebal breksi minimal $5 \mathrm{~m}$, beberapa bagian berwarna kemerahan, akibat pernah berada di bawah airlaut. Breksi dan lava andesit basaltis masif juga ditumpangi oleh aglomerat

Analisis interkoneksi jelajah alam geologi gunung api purba Gunung Ireng dengan beberapa destinaasi wisata lain yang telah diketahui wisatawan dengan baik

\begin{tabular}{|c|c|c|c|c|}
\hline VARIABEL & TEBING BREKSI & $\begin{array}{c}\text { GUNUNG } \\
\text { NGLANGGERAN }\end{array}$ & DLINGO & $\begin{array}{l}\text { GUNUNG } \\
\text { IRENG }\end{array}$ \\
\hline $\begin{array}{l}\text { JUMLAH } \\
\text { KUNJUNGAN } \\
\text { PADA HARI } \\
\text { LIBUR KHUSUS }\end{array}$ & $\begin{array}{l}20000 \text { pengun-jung } \\
\text { pada } 8 \text { Juni } 2019\end{array}$ & $\begin{array}{l}2000 \text { pengunjung pada } \\
\text { tanggal } 6 \text { Juni } 2019\end{array}$ & $\begin{array}{l}\text { 2000 pengun- } \\
\text { jung pada } 10 \\
\text { Juni } 2019\end{array}$ & $\begin{array}{l}\text { 20-40, ramai di } \\
\text { pagi (sun rise) dan } \\
\text { sore (sun set) }\end{array}$ \\
\hline ACCESIBILITIES: & $\begin{array}{l}\text { Jalan kabupaten bagus } \\
\text { dan jalan desa lebar } \\
>8 \text { m kondisi baik,ada } \\
\text { moda penghubung }\end{array}$ & $\begin{array}{l}\text { Jalan Kabupaten } \\
\text { kondisi baik, tanpa } \\
\text { moda penghubung, } \\
\text { arus datang dan arus } \\
\text { balik terpisah. }\end{array}$ & $\begin{array}{l}\text { Jalan kabupaten } \\
\text { lebar dan baik, } \\
\text { ada moda } \\
\text { penghubung }\end{array}$ & $\begin{array}{l}\text { Jalan kabupaten } \\
\text { rusak dan sempit } \\
\text { (lebar 3,5-4m), } \\
\text { tanpa moda } \\
\text { penghubung. }\end{array}$ \\
\hline ACOMODATION: & $\begin{array}{l}\text { Hotel, motel, } \\
\text { homestay dan guest } \\
\text { house terdekat } 1- \\
5 \mathrm{~km} \text {, harga Rp. } 100 \mathrm{k}- \\
500 \mathrm{k} \text {, rumah } \\
\text { makan/restoran } \\
\text { berbagai kelas, paket } \\
\text { wisata, dan oleh-oleh }\end{array}$ & $\begin{array}{l}\text { Homestay dan guest } \\
\text { house terdekat } 1-5 \mathrm{~km} \text {, } \\
\text { harga Rp. } 100 \mathrm{k}-500 \mathrm{k} \text {, } \\
\text { rumah makan/ } \\
\text { restoran berbagai } \\
\text { kelas, paket wisata, } \\
\text { dan sentra oleh-oleh }\end{array}$ & $\begin{array}{l}\text { Homestay } \\
\text { terdekat } 0,1- \\
5 \mathrm{~km} \text { harga Rp. } \\
\text { 90k-470k, } \\
\text { rumah makan/ } \\
\text { restoran 0km, } \\
\text { paket wisata, } \\
\text { oleh-oleh. }\end{array}$ & $\begin{array}{l}\text { Guesthouse } \\
\text { terdekat } 2,5 \mathrm{~km} \\
\text { (10menit). } \\
\text { rumah makan/ } \\
\text { restoran } 2,5 \mathrm{~km} \text {, } \\
\text { ada paket wisata, } \\
\text { sentra oleh-oleh } \\
\text { terdekat } 4 \mathrm{~km} .\end{array}$ \\
\hline AMENITIES: & $\begin{array}{l}\text { Jaringan telepon, } \\
\text { tempat penukaran } \\
\text { uang, ATM, toko, } \\
\text { restoran, toilet } \\
\text { bersih, kantor pos, } \\
\text { cinderamata, pasar, } \\
\text { dan internet. }\end{array}$ & $\begin{array}{l}\text { Jaringan telepon, } \\
\text { tempat penukaran } \\
\text { uang, toko, restoran, } \\
\text { toilet yang memadai, } \\
\text { cinderamata, pasar, } \\
\text { dan internet }\end{array}$ & $\begin{array}{l}\text { Jaringan } \\
\text { telepon, tempat } \\
\text { penukaran } \\
\text { uang, ATM, } \\
\text { toko, restoran, } \\
\text { toilet yang } \\
\text { memadai, }\end{array}$ & $\begin{array}{l}\text { Kebanyakan } \\
\text { jaringan telepon } \\
\text { seluler tidak } \\
\text { tertangkap } \\
\text { dengan baik, } \\
\text { internet belum } \\
\text { ada }\end{array}$ \\
\hline
\end{tabular}

ISSN: 2355-6587, e-ISSN: 2528-2220

http://ejournal.bsi.ac.id/ejurnal/index.php/jp 


\begin{tabular}{|c|c|c|c|c|}
\hline & & & $\begin{array}{l}\text { cinderamata, } \\
\text { pasar, internet }\end{array}$ & \\
\hline ACTIVITIES: & $\begin{array}{l}\text { Berjalan santai, } \\
\text { menonton } \\
\text { pertunjukan sambil } \\
\text { menikmati } \\
\text { pemandangan dan } \\
\text { keindahan karya } \\
\text { seni yang dipahat } \\
\text { pada dinding batu } \\
\text { bekas tambang }\end{array}$ & $\begin{array}{l}\text { Berjalan jelajah alam, } \\
\text { menikmati danau dan } \\
\text { alam bebatuan, dan } \\
\text { belajar geologi } \\
\text { gunung api purba }\end{array}$ & $\begin{array}{l}\text { Berjalan santai, } \\
\text { menikmati } \\
\text { pemandangan } \\
\text { alam dan udara } \\
\text { segar khas } \\
\text { perbukitan, } \\
\text { memetik } \\
\text { bebuahan dan } \\
\text { camping }\end{array}$ & $\begin{array}{l}\text { Berjalan pada } \\
\text { lereng miring } \\
\text { berbatu dan } \\
\text { menantang, } \\
\text { menikmati udara } \\
\text { segar di pagi dan / } \\
\text { sore hari, } \\
\text { mempelajari } \\
\text { geologi gunung ap } \\
\text { purba dipandu oler } \\
\text { pemandu wisata. }\end{array}$ \\
\hline ATRACTION: & $\begin{array}{l}\text { Berhubungan } \\
\text { dengan karya seni } \\
\text { pahat batu bekas } \\
\text { penambangan }\end{array}$ & $\begin{array}{l}\text { Berhubungan dengan } \\
\text { pantai dan kuliner } \\
\text { pantai }\end{array}$ & $\begin{array}{l}\text { Berhubungan } \\
\text { dengan alam, } \\
\text { flora, kebun } \\
\text { buah, } \\
\text { pertunjukan dan } \\
\text { segarnya udara } \\
\text { perbukitan }\end{array}$ & $\begin{array}{l}\text { Berhubungan } \\
\text { dengan alam, } \\
\text { ilmu geologi } \\
\text { gunung api }\end{array}$ \\
\hline
\end{tabular}

Tabel 2

Hasil analisis SWOT Gunung Ireng dan interkoneksinya

\begin{tabular}{|c|c|c|c|c|}
\hline & Deskripsi & & Deskripsi & Saran Perbaikan \\
\hline \multirow{7}{*}{ 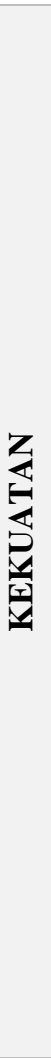 } & $\begin{array}{l}\text { 1. Memiliki kondisi geologi } \\
\text { (morfologi dan batuan) } \\
\text { lengkap untuk destinasi } \\
\text { wisata minat khusus } \\
\text { geologi gunung api purba }\end{array}$ & \multirow{7}{*}{ 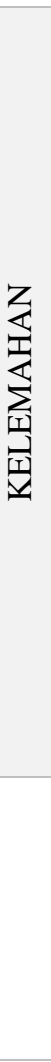 } & $\begin{array}{l}\text { Morfologi kubah } \\
\text { dengan kemiringan } \\
\text { lereng yang curam }\end{array}$ & $\begin{array}{l}\text { Diperlukan penataan } \\
\text { kawasan yang lebih baik } \\
\text { didasarkan pada } \\
\text { kelemahannya tersebut }\end{array}$ \\
\hline & $\begin{array}{l}\text { 2. Layak sebagai geoheritage } \\
\text { dan laboratorium alam } \\
\text { pembelajaran volkanologi } \\
\text { Tersier bawah laut }\end{array}$ & & $\begin{array}{l}\text { Terdeformasi } \\
\text { dengan sesar-sesar } \\
\text { dan blok-blok yang } \\
\text { bergerak }\end{array}$ & $\begin{array}{l}\text { Perlu dilengkapi kajian } \\
\text { geoteknis dengan disain } \\
\text { teknis terrinci }\end{array}$ \\
\hline & $\begin{array}{l}\text { 3. Telah memiliki master } \\
\text { plan geowisata dan } \\
\text { geoheritage yang } \\
\text { tersusun baik. }\end{array}$ & & $\begin{array}{l}\text { 3. Tidak didukung } \\
\text { dengan sumberdaya } \\
\text { airtanah yang } \\
\text { memadai }\end{array}$ & $\begin{array}{l}\text { Analisis hidrogeologi batas } \\
\text { Formasi Semilir (bawah) } \\
\text { dan Nglanggeran (atas) }\end{array}$ \\
\hline & $\begin{array}{l}\text { 4. Pilihan stop site banyak } \\
\text { dan bervariasi }\end{array}$ & & $\begin{array}{l}\text { 4. Sangat panas pada } \\
\text { musim kemarau dan } \\
\text { bermedan sulit }\end{array}$ & $\begin{array}{l}\text { Perlu jalur khusus dengan } \\
\text { berbagai penambahan jalur } \\
\text { tracking yang memadai }\end{array}$ \\
\hline & $\begin{array}{l}\text { 5. Status kepemilikan lahan } \\
\text { Gunung Ireng adalah } \\
\text { "Sultan Ground" }\end{array}$ & & $\begin{array}{l}\text { 5. Belum ada lahan } \\
\text { parkir, status lahan } \\
\text { sekitar milik warga }\end{array}$ & $\begin{array}{l}\text { Diperlukan pembebasan } \\
\text { lahan untuk lahan parkir } \\
\text { dan tambahannya }\end{array}$ \\
\hline & $\begin{array}{l}\text { 6. Sebagian besar warga } \\
\text { Srumbung (Pengkok) } \\
\text { mendukung } \\
\text { pengembangannya }\end{array}$ & & $\begin{array}{l}\text { 6. Masih ada sebagian } \\
\text { warga Ngrancahan } \\
\text { yang belum } \\
\text { menyetujuinya }\end{array}$ & $\begin{array}{l}\text { Perlu pendekatan untuk } \\
\text { meyakinkan warga tentang } \\
\text { wisata jelajah alam geologi } \\
\text { gunung api purba }\end{array}$ \\
\hline & $\begin{array}{l}\text { 7. Sun set dan sun rise di } \\
\text { Gunung Ireng yang telah } \\
\text { lebih dulu dikenal luas }\end{array}$ & & $\begin{array}{l}\text { 7. Pengunjung masih } \\
\text { lokal dari kawasan } \\
\text { di sekitarnya }\end{array}$ & $\begin{array}{l}\text { Dibangun interkoneksi } \\
\text { kontinyu, membangun url } \\
\text { dan jejaring sosial bisnis }\end{array}$ \\
\hline \multirow{2}{*}{ 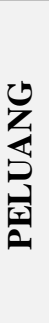 } & $\begin{array}{l}\text { 1. Sangat diinginkan oleh } \\
\text { masyarakat luas, sebagai } \\
\text { wahana wisata jelajah } \\
\text { alam minat khusus yang } \\
\text { menantang }\end{array}$ & \multirow{2}{*}{$\sum_{\substack{Z \\
Z}}^{Z}$} & $\begin{array}{l}\text { 1. Terdapat destinasi } \\
\text { wisata lain yang } \\
\text { sama yaitu Gunung } \\
\text { api purba } \\
\text { Nglanggeran }\end{array}$ & $\begin{array}{l}\text { Pelatihan terhadap operator } \\
\text { website Gunung Ireng }\end{array}$ \\
\hline & $\begin{array}{l}\text { 2. Belum ada museum } \\
\text { geologi gunung api purba } \\
\text { di Indonesia }\end{array}$ & & $\begin{array}{l}\text { 2. Belum memiliki } \\
\text { pemandu, belum ada } \\
\text { dukungan dari HPI }\end{array}$ & $\begin{array}{l}\text { Penyelenggaraan pelatihan } \\
\text { pemandua dan pengelola } \\
\text { secara terjadwal }\end{array}$ \\
\hline
\end{tabular}

ISSN: 2355-6587, e-ISSN: 2528-2220

http://ejournal.bsi.ac.id/ejurnal/index.php/jp 


\section{Pariwisata, Vol. 6 No. 2 September 2019}

3. Berpotensi sebagai center of tourism terinterkoneksi dengan Jelok, Bukit Bintang, Jurug Gedhe

4. Memiliki POKDARWIS dan pengelola yang komitmen dari warga setempat
3. Belum didukung akses jalan yang baik dan akomodasi yang memadai

4. Sistem pengelolaan wisata yang masih belum terarah
Program pelebaran jalan, pengadaan taman parkir, dan akomodasi (hotel, resto-ran), ameniti (ATM, toilet dll)

Pelatihan pengelolaan destinasi wisata minat khusus

Aglomerat berwarna abu-abu terang kekar yang membuka. Di sisi baratdaya, kecoklatan-kemerahan-kehitaman oleh aglomerat juga menumpang di atas lava proses oksidasi di bawah permukaan air. basaltik berwarna abu-abu gelap dengan Di sisi selatan singkapan aglomerat di struktur bantal. Lava ini banyak menyusun permukaan mengalami deformasi lembah-kaki Gunung Ireng dan morfologi membentuk bidang-bidang striasi sesar dan di sebelah barat daya (Gambar 6.d).

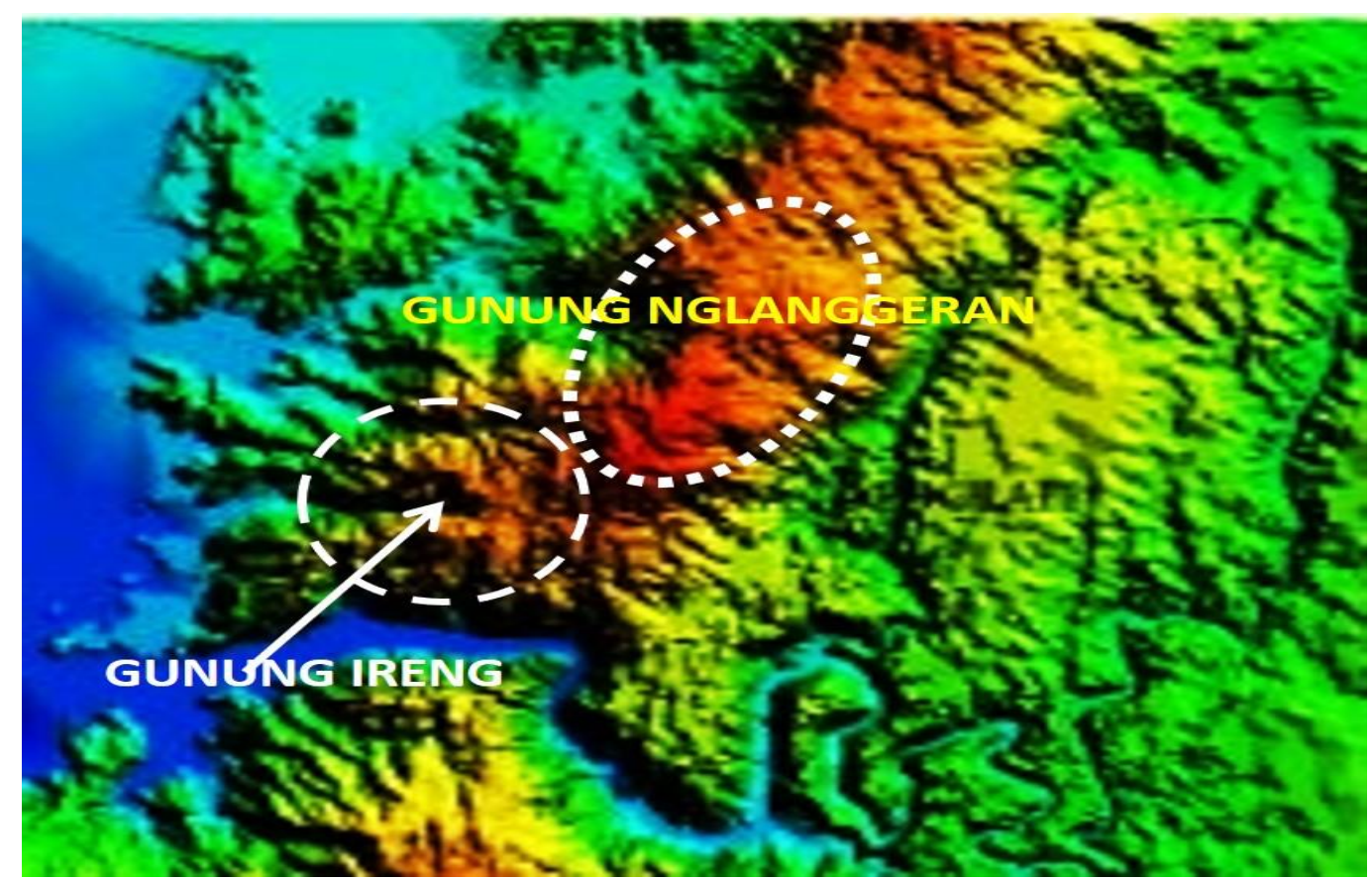

Gambar 5

Data hasil analisis DEM di daerah penelitian
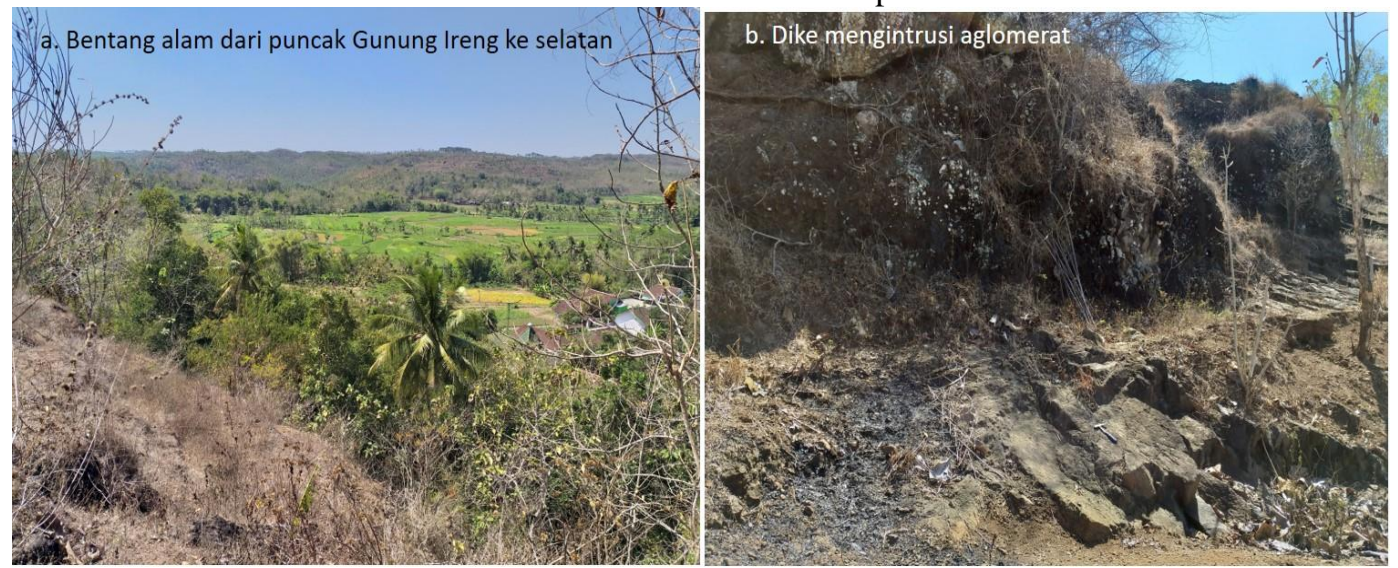

ISSN: 2355-6587, e-ISSN: 2528-2220

http://ejournal.bsi.ac.id/ejurnal/index.php/jp 


\section{Pariwisata, Vol. 6 No. 2 September 2019}

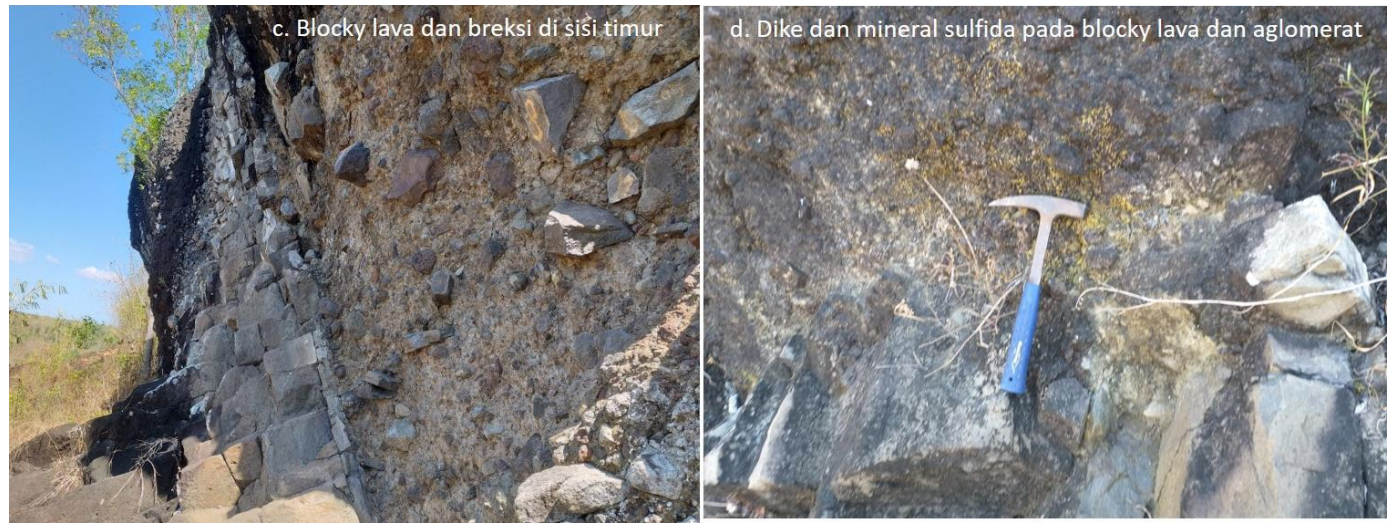

Gambar 6

Singkapan beberapa data geologi gunung api purba yang memiliki potensi mengedukasi di Gunung Ireng dari arah selatan (a, b) dan tenggara-timur (c, d)

Ke arah utara dan timur sekitar 200 m dari puncak Gunung Ireng, tersingkap tuf putih Formasi Semilir yang berada di bawah breksi andesit dan aglomerat, namun setelah dirunut sekitar $500 \mathrm{~m}$ ke utara, di tuf ini menghilang terpotong oleh sesar naik dan litologi langsung berubah menjadi breksi dan aglomerat yang secara deskriptif hampir mirip dengan yang tersingkap di Gunung Ireng, hanya saja warnanya agak kecoklatan. Aglomerat ini juga berasosiasi dengan intrusi andesit piroksen berwarna abu-abu gelap agak kehijauan. Sepertinya breksi dan aglomerat ini secara stratigrafi di bawah tuf putih Formasi Semilir. Ke arah timur, tuf Formasi Semilir makin tebal dan tidak dijumpai lagi breksi andesit dan aglomerat. Sekitar 500m ke barat dari kaki Gunung Ireng dijumpai breksi andesit basaltis, lava dan aglomerat coklat kemerahan, berbatasan dengan sesar turun dan breksi pumis abu-abu terang. Sekitar $100 \mathrm{~m}$ ke selatan dari puncak adalah lava basalt berstruktur bantal, tebal 3-5 m dengan permukaan tidak beraturan. Basalt dicirikan oleh warna abu-abu sangat gelap, berstruktur bantal, diameter bantal 60$120 \mathrm{~cm}$, berarah aliran dari baratlaut, skoriaseus, afanitik dengan komposisi piroksen klino dan plagioklas, beberapa olivin halus dalam afanit basaltis. Di atas basalt ke selatan adalah batugamping koral abu-abu kekuningan, berlapis. Di atas batugamping koral adalah perselingan batupasir karbonatan dan batugamping berlapis, terkadang dijumpai fragmen litik andesit berdiameter $2-5 \mathrm{~cm}$; tersingkap di Dusun Sumberejo. Ke arah selatan dan tenggara morfologinya didominasi oleh bentang alam perbukitan bergelombang sedang berbentuk kerucut rendah, karena tersusun atas batugamping (Gambar 5.a).
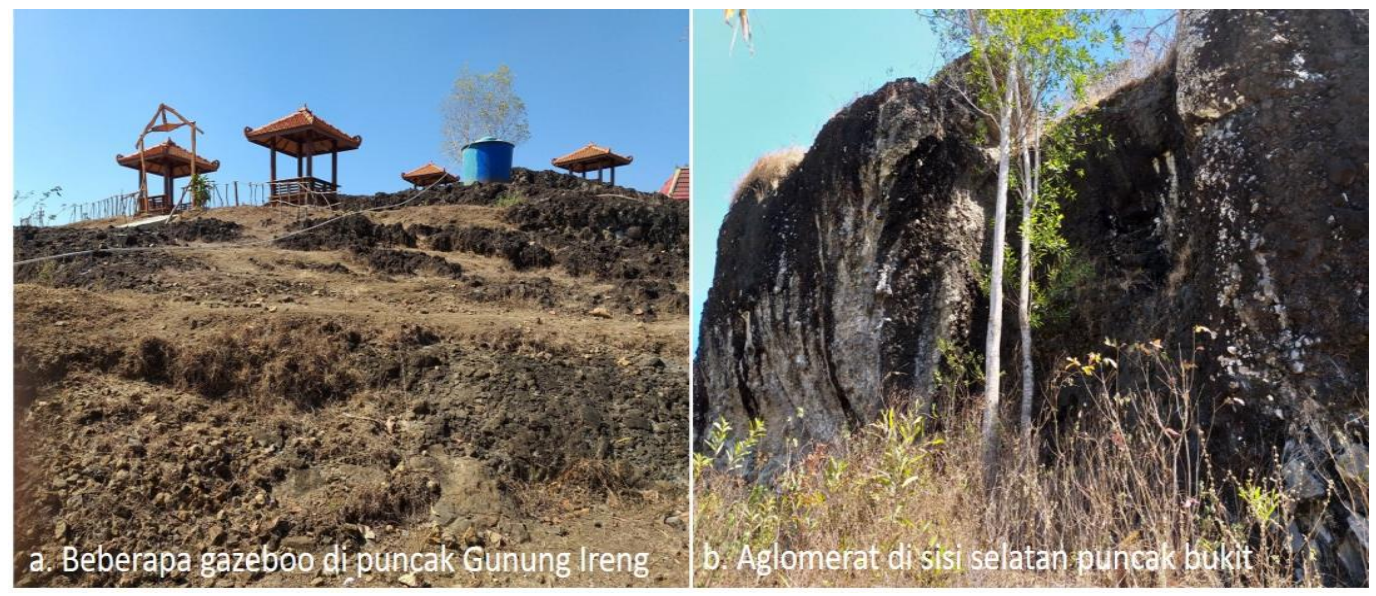

ISSN: 2355-6587, e-ISSN: 2528-2220

http://ejournal.bsi.ac.id/ejurnal/index.php/jp 


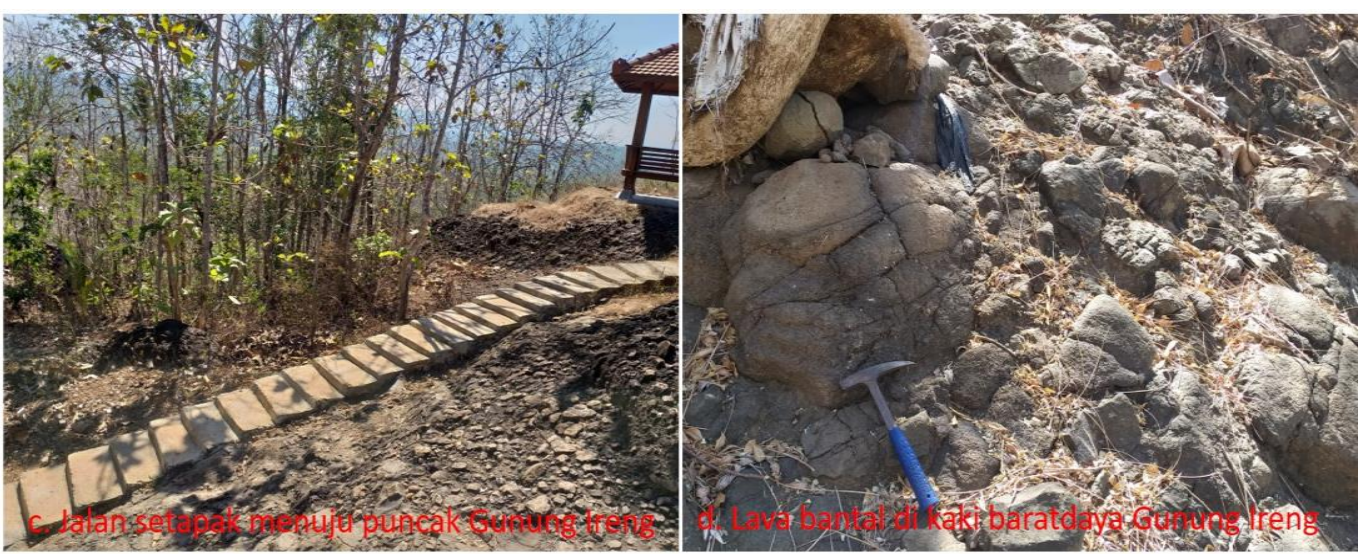

Gambar 7

Beberapa potensi data geologi lain yang dijumpai di Gunung Ireng; a-b adalah aglomerat Formasi Nglanggeran di Gunung Ireng yang juga diketahui menyusun Gunung Nglanggeran dan c-d adalah jalan setapak menuju puncak Gunung Ireng yang berada pada andesit massif di sisi utara dan lava basalt berstruktur bantal (di kaki baratdaya).

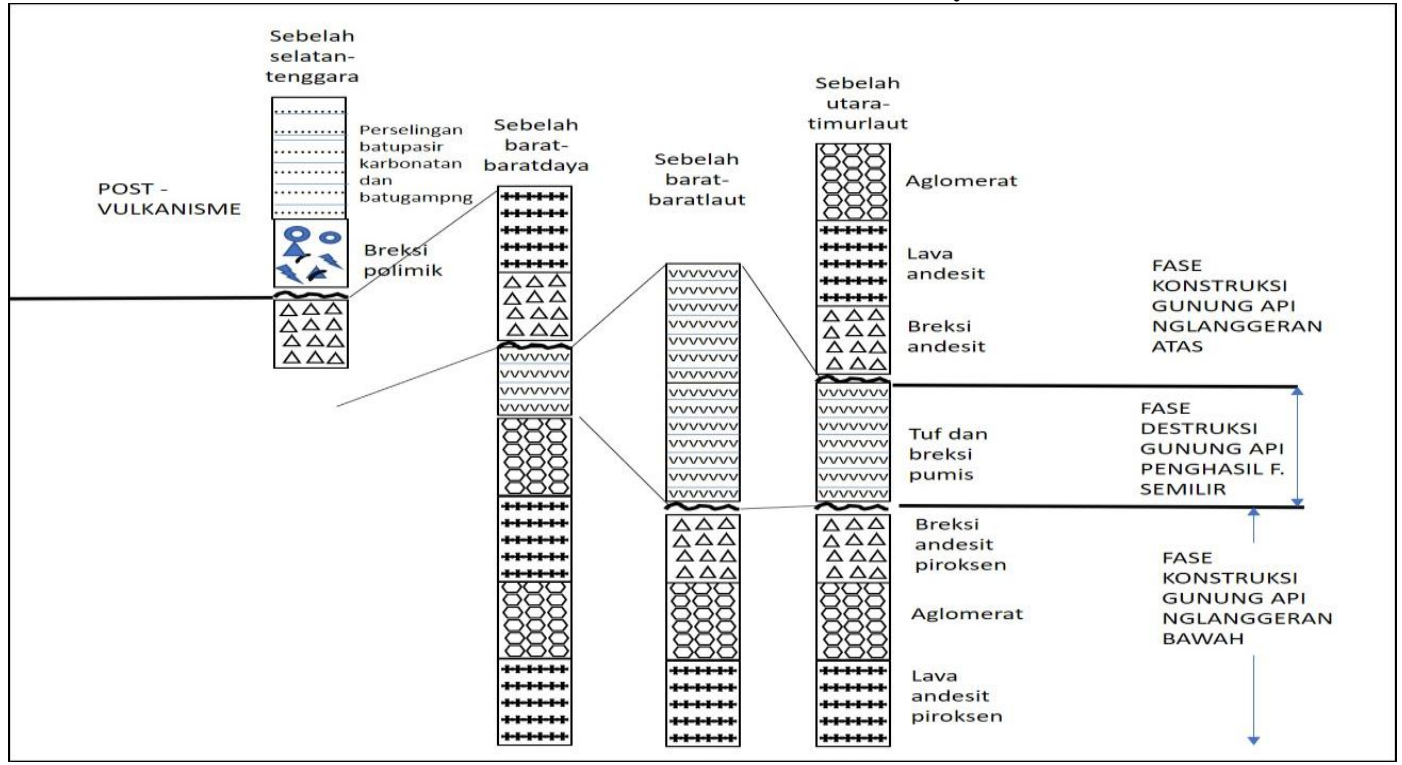

Gambar 8

Stratigrafi di sekitar Gunung Ireng dari sisi utara, barat-barat daya, selatan-tenggara (tanpa skala)

Perencanaan matang dan menyeluruh terhadap rencana pengembangan destinasi wisata jelajah alam geologi gunung api purba Gunung Ireng harus segera disusun. Kekuatan dan peluang Gunung Ireng lebih mendominasi dibandingkan dengan kelemahannya. Kekuatan utama Gunung Ireng terletak pada potensi dan keunikan geologinya, sebagai fasies pusat gunung api purba. Ide pengembangan bertolak dari upaya geokonservasi yang dikemas sebagai destinasi wisata. Kelemahan dan ancaman interkoneksi dengan destinasi-destinasi wisata lain di sekitarnya dapat diminimalisir melalui perbaikan dan pemenuhan sarana dan prasarana pendukung industri pariwisata, meliputi:

Aksesibilitas yaitu perbaikan dan pelebaran jalan kabupaten Patuk-PengkokDlingo melalui Gunung Ireng, harapannya dapat dilalui bus besar dan berpenumpang maksimal; pengadaan moda penghubung (feeder) antar destinasi wisata yang dikoneksikan dengan Gunung Ireng; dan tempat parkir yang memadai sekaligus kendaraan feeder yang menghubungkan tempat parkir dan area wisata.

(1) Akomodasi meliputi ketersediaan hotel, motel, guest house dan rumah singgah di sekitar Gunung Ireng, mengingat saat ini

ISSN: 2355-6587, e-ISSN: 2528-2220

http://ejournal.bsi.ac.id/ejurnal/index.php/jp 
event terlaris untuk dikunjungi di Gunung Ireng adalah pada pagi hari (sun rise) dan pada sore hari (sun set). Fasilitas yang lain adalah ketersediaan restoran atau rumah makan representatif yang belum tersedia di lokasi ini. Rumah makan terdekat berada di Bukit Bintang dan Patuk yang berjarak $\sim 5-7 \mathrm{~km}$ ke utara, Dlingo berjarak $\sim 7 \mathrm{~km}$ ke baratdaya dan Gedangsari yang berjarak $\sim 5 \mathrm{~km}$; (2) Amenitas meliputi telepon, tempat penukaran uang, ATM, toko, restoran, toilet yang memadai, kantor pos, cinderamata, pasar, internet, HP, telegram, dan sebagainya, yang memang masih belum tersedia.

Gunung Ireng sebagai salah satu destinasi wisata minat khusus akan menjadi andalan Kabupaten Gunungkidul; menjadi primadona saat pengelolaannya dijalankan dengan baik dan tepat. Destinasi ini akan mampu menjadi pesaing utama Gunung Nglanggeran dan mendongkrak destinasidestinasi wisata lain di sekitarnya. Hal itu akan terjadi hanya jika sistem pemasaran, pengiklanan dan promosi tepat sasaran, didukung kondisi geologi yang spesifik dan menjual.

Geologi Gunung Ireng meliputi geomorfologi, litologi dan stratigrafi, serta sejarah geologinya akan memberikan edukasi baru bagi pengunjung. Dari data stratigrafi terukur, mengacu pada Surono dkk (1992), batuan gunung api di daerah penelitian adalah bagian dari Formasi Nglanggeran. Kelompok batuan vulkanik yang berkomposisi andesit piroksen (andesit basaltis) adalah bagian dari Formasi Nglanggeran bawah, sedangkan kelompok batuan vulkanik berkomposisi andesit (dengan mineral horenblenda) adalah bagian dari Formasi Nglanggeran atas. Kedua kelompok batuan tersebut dijumpai di daerah penelitian, tanpa dibatasi oleh breksi pumis dan / atau tuf. Sedangkan di lokasi yang lain dapat dijumpai keduanya dengan dibatasi oleh kelompok batuan vulkanik Formasi Semilir tersebut.

Didasarkan pada data stratigrafi tersebut, secara berurutan, dari tua ke muda di daerah Gunung Ireng telah berlangsung aktivitas gunung api yang berkomposisi andesit basaltis. Pada periode berikutnya, di sisi lain dari gunung api ini terjadi fasa destruksi gunung api dengan letusan yang bersifat menghancurkan tubuh kerucut gunung api membentuk kelompok batuan Formasi Semilir. Pengendapan batuan vulkanik Formasi Semilir sangat luas, namun ada beberapa lokasi secara lokal tidak berlangsung pengendapan, atau jika berlangsung digerus atau dihancurkan oleh aktivitas gunung api setelahnya yang bersifat membangun menghasilkan Formasi Nglanggeran bagian atas. Daerahdaerah tersebut utamanya berada pada fasies pusat gunung api. Fasa selanjutnya adalah konstruksi gunung api kedua menghasilkan Formasi Nglanggeran bagian atas. Gunung api ini berada di bawah perairan / lakustrin, dengan ditunjukkan oleh warna hitam kemerahan pada batuan gunung api Gunung Ireng, yang terbentuk oleh proses oksidasi bawah air. Di sisi selatan, mungkin bersamaan dengan aktivitas vulkanisme dan atau setelahnya, pada awalnya lingkungan sedimentasinya dipengaruhi aktivitas vulkanisme menghasilkan batuan epiklastika yang diendapkan di lingkungan laut. Makin ke atas, vulkanisme semakin menurun hingga didominasi oleh lingkungan laut, membentuk sedimen karbonatan.

\section{PENUTUP}

Dapat disimpulkan bahwa Gunung Ireng adalah satu destinasi wisata yang berpotensi dapat dikembangkan sebagai jalur minat khusus geologi gunung api purba. Daerah ini memiliki kondisi geologi berupa bekas pusat aktivitas gunung api (kawah).

Pengelolaan kawasan wisata dengan didukung perbaikan dan pengadaan sarana dan prasarana untuk mendukung industri pariwisata menjadi kunci dalam keberhasilannya.

\section{REFERENSI}

Andrews, G.D., Branney, M.J., Bonnichsen, B. and McCurry, M., (2008). Rhyolitic ignimbrites in the Rogerson Graben, southern Snake River Plain volcanic province: volcanic stratigraphy, eruption 
history and basin evolution. Bulletin of Volcanology, 70(3), pp.269-291.

Andriany, S.S., Fatimah, M.R. and Hardiyono, A., (2016). Geowisata Geopark Ciletuh: Geotrek Mengelilingi Keindahan Mega Amfiteater Ciletuh (The Magical of Ciletuh Amphitheater). Bulletin of Scientific Contribution: GEOLOGY, 14(1), pp.75-88.

Al-Bakry, M.H.N., (2013). Strategi Pemasaran Objek Wisata Kebun Buah Di Desa Mangunan Kecamatan Dlingo Kabupaten Bantul Untuk Meningkatkan Jumlah Kunjungan Wisatawan. Jurnal Kepariwisataan, 7(1), pp.29-40.

Annisaa, N.A., (2016). Pelestarian Kawasan Warisan Geologi Gunungapi Purba Nglanggeran Sebagai Geowisata Kecamatan Patuk, Kabupaten Gunung Kidul Daerah Istimewa Yogyakarta (Doctoral dissertation, UPN" Veteran" Yogyakarta).

Arbainah, S., (2014). Pemasaran Bersama Berbasis ICT sebagai Media Promosi Alternatif bagi UMKM Desa Wisata. Jurnal Akuntansi Bisnis dan Perbankan Indonesia, 22(2).

Arce, J.L., Walker, J. and Keppie, J.D., (2014). Petrology of two contrasting Mexican volcanoes, the Chiapanecan (El Chichón) and Central American (Tacaná) volcanic belts: the result of rift-versus subduction-related volcanism. International Geology Review, 56(4), pp.501-524.

Blessia, S., Mulyaningsih, S., Tania, D. and Heriyadi, N.W.A.A.T., (2019). Vulkano-Stratigrafi Gunung Ireng, Desa Pengkok, Kecamatan Patuk, Kabupaten Gunungkidul-DIY. Jurnal Teknomineral, 1(1), pp.2433.

Budayana, I.G.N.M, (2017). Geologi dan Identifikasi Fasies Gunung Api Berdasarkan Stratigrafi Batuan di Daerah Mangunan dan Sekitarnya, Kecamatan Dlingo, Kabupaten Bantul Daerah Istimewa
Yogyakarta, Laporan Sripsi Tipe-1, 2017; tidak dipublikasikan.

Darsiharjo, D., (2016). Pengembangan Geopark Ciletuh berbasis partisipasi masyarakat sebagai kawasan geowisata di kabupaten Sukabumi. Jurnal Manajemen Resort dan Leisure, 13(1).

Dominikus, D., (2018). Pengembangan Desa Wisata (Penelitian Obyek Wisata Tebing Breksi di Desa Sambirejo, Kecamatan Prambanan, Kabupaten Sleman, Yogyakarta).

Evita, R., Sirtha, I.N. and Sunartha, I.N., (2012). Dampak perkembangan pembangunan sarana akomodasi wisata terhadap pariwisata berkelanjutan di bali. Jurnal Ilmiah Pariwisata. Denpasar: Universities Udayana.(16 Juni 2014, 6: 05 PM).

Ginting, N., Rahman, N.V. and Sembiring, G., (2017). March. Tourism Development Based on Geopark in Bakkara Caldera Toba, Indonesia. In IOP Conference Series: Materials Science and Engineering (Vol. 180, No. 1, p. 012086). IOP Publishing.

Hadian, M.S.D., Yuliwati, A.K. and Pribadi, K.N., (2016). Increasing community environmental awareness through geodiversity conservation activities at Ciletuh, Sukabumi, West Java. Journal of Environmental Management \& Tourism, 7(2), p.14.

Hermawan, H., (2017). Pengaruh Daya Tarik Wisata, Keselamatan, Dan Sarana Wisata Terhadap Kepuasan Serta Dampaknya Terhadap Loyalitas Wisatawan: Studi Community Based Tourism Di Gunung Api Purba Nglanggeran. JURNAL MEDIA WISATA: Wahana Informasi Pariwisata, 15(1).

Hermawan, H. and Brahmanto, E., (2017). Geowisata: Perencanaan Pariwisata Berbasis Konservasi.

Hermawan, H., (2018). Geowisata Sebagai Model Pemanfaatan Kekayaan Geologi Yang Berwawasan Lingkungan. Jurnal online (STP AMPTA Yogyakarta, diakses tanggal 23 April 2018). 
Hermawan, H. and Ghani, Y.A., (2018). Geowisata: Solusi Pemanfaatan Kekayaan Geologi Yang Berwawasan Lingkungan. Jurnal Sains Terapan Pariwisata, 3(3), pp.391-408.

Kusumayudha, S.B., Setiawan, J., Ciptahening, A.N. and Dwi Septianta, P., (2015). Geomorphologic model of Gunungsewu karst, Gunung Kidul Regency, Yogyakarta Special Territory, Indonesia: The role of lithologic variation and geologic structure. Journal of Geological Resource and Engineering, 3(1), pp.1-7.

Martiarini, R., (2017). Strategi Pengembangan Desa Wisata Melalui Pemberdayaan Masyarakat Desa Ketenger Baturraden (Doctoral dissertation, IAIN).

Mulyaningsih, S., Blessia, S., Tania, D. and Heriyadi, N.W.A.A.T., (2019a). Studi Fasies Gunung Api Purba Gunung Ireng, Desa Pengkok, Kecamatan Patuk, Kabupaten Gunungkidul-DIY. Jurnal Teknomineral, 1(1), pp.15-23.

Mulyaningsih, S., Suhartono, dan Mindayani, E., (2019b). Kajian Potensi Pengembangan Jalur Jelajah Alam Geologi gunung Api Purba Giriloyo-Imogiri, Jurnal Riset Daerah, in press.

Mulyaningsih, S., 2015. Vulkanologi. Yogyakarta: Penerbit Ombak.

Nurjanah, R., (2012). Studi Persepsi Dampak Perubahan Pemanfaatan Lahan Terhadap Kunjungan Wisata di Pulau Pramuka Kepulauan Seribu. Journal of Regional and City Planning, 23(2), pp.139-156.

Permadi, R., Rachwibowo, P. and Hidajat, W.K., (2014). Potensi Situs-Situs Warisan Geologi di Area Kars Gunung Sewu sebagai Pendukung dan Peluang Pengembangan Geopark di Indonesia untuk Aset Geowisata Kreatif. Geological Engineering E-Journal, 6(2), pp.586-601.
Pratama, N.B. and Kistini, K., (2013). Aktivitas Industri Kerajinan Topeng Kayu Di Desa Wisata Bobung, Kecamatan Patuk, Gunungkidul, Daerah Istimewa YOGYAKARTA. Jurnal Bumi Indonesia, 2(1).

Purbasari, N. and Asnawi, A., (2014). Keberhasilan community based tourism di desa wisata Kembangarum, Pentingsari dan Nglanggeran. Teknik PWK (Perencanaan Wilayah Kota), 3(3), pp.476-485.

Raharjana, D.T., (2012). Membangun pariwisata bersama rakyat: Kajian partisipasi lokal dalam membangun Desa wisata di dieng plateau. Jurnal Kawistara, 2(3).

Rahmawati, H.A., (2017). Pengembangan Destinasi Wisata Taman Tebing Breksi di Dusun Nglengkong Desa Sambirejo Prambananan Sleman (Doctoral dissertation, Universitas Gadjah Mada).

Rosida, I., (2014). Partisipasi Pemuda dalam Pengembangan Kawasan Ekowisata dan Implikasinya Terhadap Ketahanan Masyarakat Desa (Studi di Kawasan Ekowisata Gunung Api Purba Nglanggeran, Desa Nglanggeran, Kecamatan Patuk, Kabupaten Gunung Kidul, DIY. Jurnal Ketahanan Nasional, 20(2), pp.47-46.

Sidarta, I.W.T., (2002). Dampak Perkembangan Pariwisata Terhadap Kondisi Lingkungan, Sosial dan Ekonomi Masyarakat (Studi Kasus Kawasan Pariwisata Sanur, Denpasar-Bali) (Doctoral dissertation, Program Pascasarjana Universitas Diponegoro).

Simbolon, J.H., Blessia, S., Mulyaningsih, S., Tania, D. and Heriyadi, N.W.A.A.T., (2019). Petrologi Batuan Gunung Api Gunung Ireng, Desa Pengkok, Kecamatan Patuk, Kabupaten Gunungkidul-DIY. Jurnal Teknomineral, l(1), pp.1-14.

Smyth, H.R., Hall, R. and Nichols, G.J., (2008). Cenozoic volcanic arc history of East Java, Indonesia: the stratigraphic record of eruptions on

ISSN: 2355-6587, e-ISSN: 2528-2220 
an active continental margin. Special Papers-Geological Society of America, 436, p.199.

Surono, B.T. and Sudirno, I., (1992). Peta Geologi Lembar SurakartaGiritontro. Jawa.(1408-3), Skala1, 100.

Surgawi, I. and Sutopo, S., (2016). Analisis Pengaruh Produk Wisata, Persepsi Harga dan Promosi terhadap Keputusan Wisatawan dalam Mengunjungi Objek Wisata (Studi pada Objek Wisata Puri Maerokoco Kota Semarang) (Doctoral dissertation, Fakultas Ekonomika dan Bisnis).

Syakdiah, S., (2018). Dynamics of Tourism in Special District of Yogyakarta. Prosiding Semnasfi, l(1), pp.225-233.

Tyas, D.N., Vitdiawati, R. and Nusantari, R., (2016). Konservasi dan Pemanfaatan Berkelanjutan Kawasan Karst Gunung Sewu sebagai Bagian Geopark untuk Mempertahankan Fungsi Ekologi. In Symbion (Symposium on Biology Education): Proceeding, Departement of Biology Universitas Ahmad Dahlan.

Umardiono, A., (2011). Pengembangan obyek wisata Taman Nasional Laut Kepulauan Karimun Jawa. Jurnal Unair, 24(3), pp.192-201.

Wang, S. and Xu, H., (2015). Influence of place-based senses of distinctiveness, continuity, selfesteem and self-efficacy on residents' attitudes toward tourism. Tourism Management, 47, pp.241250.

Yuliawati, A.K., Hadian, M.S.D., Rahayu, A. and Hurriyati, R., (2016). Developing geotourism as part of sustainable development at Ciletuh Sukabumi, West Java, Indonesia. Journal of Advanced Research in Management, 7(1), pp.57-62.

Zakaria, Z., (2018). Prospective Analysis of Sustainable Development Strategy of Geopark Tourism of
Ciletuh Palabuhanratu West Java Indonesia.

\section{BIOGRAFI PENULIS}

Sri Mulyaningsih lahir pada 3 Juni 1972 di Sleman Yogyakarta, telah menyelesaikan pendidikan program doktor pada tahun 2006 dari Departemen Teknik Geologi-FIKTM Institut Teknologi Bandung. Sepanjang kariernya, yang bersangkutan aktif melakukan penelitian tentang geowisata dan vulkanologi, serta implikasinya bagi lingkungan. Saat ini, menjadi staf pengajar di Jurusan Teknik Geologi - FTM Institut Sains \& Teknologi AKPRIND Yogyakarta.

Nur Widi A.A.T. Heriyadi lahir di Sleman pada tanggal 15 Agustus 1979, menyelesaikan pendidikan S2 pada program studi Teknik Geologi-FTM UPN Veteran Yogyakarta pada tahun 2015. Saat ini aktif melakukan penelitian dan kajiankajian tentang sifat keteknikan batuan; serta aktif sebagai staf pengajar di Jurusan Teknik Geologi - FTM Institut Sains \& Teknologi AKPRIND Yogyakarta.

Dina Tania lahir di Bangka pada tanggal 13 Mei 1982, menyelesaikan pendidikan S2 pada program studi Teknik GeologiFTM UPN Veteran Yogyakarta pada tahun 2015. Saat ini aktif melakukan penelitian dan kajian-kajian tentang Paleontologi dan Sedimentologi; serta aktif sebagai staf pengajar di Jurusan Teknik Geologi - FTM Institut Sains \& Teknologi AKPRIND Yogyakarta.

Suhartono lahir pada 16 Juni 1959 di Sleman Yogyakarta, telah menyelesaikan pendidikan S2 pada tahun 1998 dari Departemen Teknik Industri-Fakultas Teknologi Industri Institut Teknologi Sepuluh Nopember Surabaya (ITS). Sepanjang kariernya, yang bersangkutan aktif melakukan penelitian tentang manajemen dan industri pariwisata, serta implikasinya bagi lingkungan. Saat ini, menjadi staf pengajar di Jurusan Teknik Industri Universitas Widya Mataram Yogyakarta.

ISSN: 2355-6587, e-ISSN: 2528-2220 